\title{
A Comparative Study on the Analgesic Efficacy of Bilateral Suprazygomatic Maxillary Nerve Block Under Ultrasound Guidance with 0.25\% Bupivacaine and 0.25\% Bupivacaine with Dexmedetomidine in Paediatric Patients Undergoing Cleft Palate Repair - A Randomized Prospective Double Blinded Study
}

\author{
Yarık Damak Onarımı Uygulanan Pediatrik Hastalarda Ultrason Eşliğinde \\ $\% 0,25$ Bupivakain veya \%0,25 Bupivakain ve Deksmedetomidin ile Bilateral \\ Suprazigomatik Maksiller Sinir Bloğunun Analjezik Etkinliği Üzerine \\ Karşılaştırmalı Bir Çalışma - Randomize Prospektif Çift Kör Çalışma
}

\author{
Arul Murugan Ramasamy, Senthil Kumar Sukumar, Prabavathi Srinivasan, Venkata Rajesh Kumar Kodali, \\ Akilandeswari Manickam, Aruna Parameswari, Mahesh Vakamudi \\ Sri Ramachandra Institute of Higher Education and Research (SRIHER), Department of Anesthesiology, Porur, Chennai, India
}

\section{ABSTRACT}

Objective: Cleft palate repair involves surgery on the both hard and soft palate leading to severe pain, intense sympathetic stimulation, and bleeding. In our study we analysed the analgesic efficacy of bupivacaine alone and bupivacaine with dexmedetomidine in ultrasound guided bilateral suprazygomatic maxillary nerve block (SMN) for cleft palate repair.

Methods: This study was a randomized prospective doubleblinded study. Fourty six children of the ASA class I and II posted for cleft palate repair were randomized into Group A and Group B. In Group A, 23 children had SMN block with $0.15 \mathrm{~mL} \mathrm{~kg}^{-1}$ of $0.25 \%$ bupivacaine with saline and the same procedure was repeated on other side. In Group B, 23 children received SMN block with a volume of $0.15 \mathrm{~mL} \mathrm{~kg}^{-1}$ of $0.25 \%$ bupivacaine with dexmedetomidine $0.5 \mu \mathrm{gg}^{-1}$ on each side. Primary outcomes analysed were pain scores in post operative period by Children and Infants Post-Operative Pain Scale (CHIPPS) and the analgesia duration. Postoperative pain scores were analysed at 30 minutes intervals for 2 hours in Post Anaesthesia Care Unit (PACU) and at every 2 hours interval for 24 hours in the postoperative ward.

Results: Group A and B were comparable in demographic variables like age, gender, weight, ASA status, and duration of surgery. Children in Group B had significantly longer duration of analgesia when compared to that of Group A $(12 \pm 4.73$ hours vs $5.41 \pm 3.9$ hours) $(p=0.003)$. Children had significantly lower pain scores in Group B at zero min in PACU $(p=0.04)$, after $90 \mathrm{~min}(p=0.02)$, at 2 hours $(p<0.001), 4$ hours $(p<0.001), 6$ hours $(p=0.006)$ and at 8 hours $(p=0.02)$ when compared to that in Group A.
Öz

Amaç: Yarık damak onarımı, şiddetli ağrı, yoğun sempatik uyarı ve kanamaya yol açan hem sert hem de yumuşak damak cerrahisini içerir. Çalışmamızda yarık damak onarımı için ultrasonografi eşliğinde uygulanan bilateral suprazigomatik maksiller sinir (SMS) bloğunda tek başına bupivakainin ve deksmedetomidin ile bupivakainin analjezik etkinliğini inceledik.

Yöntem: Bu randomize, prospektif, çift kör çalışmada, yarık damak onarımı geçirecek, ASA fiziksel sınıflaması sınıf I ve II olan 46 çocuk Grup A ve Grup B'ye randomize edildi. Grup A'da, 23 çocuğa $0,15 \mathrm{~mL} \mathrm{~kg}^{-1}$ hacimde salin içinde $\% 0,25$ bupivakainle SMN bloğu uygulandı ve aynı işlem diğer taraf için de tekrarlandı. Grup B'de, 23 çocuğa her iki tarafa $0,15 \mathrm{~mL} \mathrm{~kg}^{-1}$ hacimde, $0,5 \mu \mathrm{g} \mathrm{kg}^{-1}$ deksmedetomidin ve $\% 0,25$ bupivakain ile SMN blok uygulandı. Analiz edilen birincil sonuçlar, postoperatif dönemde çocuk ve infantların postoperatif ağrı ölçeği (CHIPPS) ile değerlendirilen ağrı skorları ve analjezi süresiydi. Postoperatif ağrı skorları, anestezi sonrası bakım ünitesinde (PACU) 2 saat boyunca 30 dakika aralıklarla, serviste 24 saat boyunca 2 saatte bir analiz edildi.

Bulgular: Grup A ve B, yaş, cinsiyet, ağırlık, ASA ve ameliyat süresi gibi demografik değişkenler açısından benzerdi. Grup B'deki çocuklar, Grup A'ya kıyasla ( $12 \pm 4,73$ saate karşı $5,41 \pm 3,9$ saat) anlamlı olarak daha uzun analjezi süresine sahipti $(p=0,003)$. Grup B'deki çocukların, PACU'da sıfirıncı dakikada $(p=0,04), 90$ dakikadan sonra $(p=0,02), 2$. saatte $(p<0,001), 4$. saatte $(p=0,04)$, 6. saatte $(p=0,006)$ ve 8 . saatte $(p=0,02)$ Grup A'dakine kıyasla anlamlı olarak daha düşük ağrı skorları vardı.

\footnotetext{
Received/Geliş tarihi : 03.06.2021

Accepted/Kabul tarihi : 11.10 .2021

Publication date $\quad$ :28.01.2022

*Corresponding author: Venkata Rajesh Kumar Kodali • vrajesh.kodali@gmail.com

Arul Murugan Ramasamy (1) 0000-0001-9805-9761 / Senthil Kumar Sukumar 이 0000-0003-0407-7788

Prabavathi Srinivasan (1) 0000-0001-9401-884X / Venkata Rajesh Kumar Kodali @ 0000-0002-4467-6657

Akilandeswari Manickam 두 0000-0003-4576-391X / Aruna Parameswari 구 0000-0002-1280-5047

Mahesh Vakamudi (10) 0000-0002-6029-9185
}

Cite as: Ramasamy AM, Sukumar SK, Srinivasan P, Kodali VRK, Manickam A, Parameswari A, Vakamudi M. A comparative study on the analgesic efficacy of bilateral suprazygomatic maxillary nerve block under ultrasound guidance with $0.25 \%$ bupivacaine and $0.25 \%$ bupivacaine with dexmedetomidine in paediatric patients undergoing cleft palate repair - A randomized prospective double blinded study. JARSS 2022;30(1):1-8. 
Conclusion: Children who received bupivacaine with dexmedetomidine in SMN block had a longer analgesia duration and lesser postoperative pain scores than children who received bupivacaine alone.

Keywords: Maxillary nerve block, Dexmedetomidine, pain scores, postoperative analgesia, rescue analgesia
Sonuç: Deksmedetomidin ve bupivakainle SMS bloğu uygulanan çocuklarda tek başına bupivakainle blok yapılan çocuklara göre analjezi süresi daha uzundu ve postoperatif ağrı skorları daha düşüktü.

Anahtar sözcükler: Maksiller sinir bloğu, deksmedetomidin, ağrı skorları, postoperatif analjezi, kurtarıcı analjezi

\section{INTRODUCTION}

Orofacial cleft includes a wide range of abnormalities with in the oral cavity and facial structures which in turn manifested as oral, facial and craniofacial deformity. These deformities may present as cleft lip, cleft palate alone or as a combination of both cleft lip and palate. This anomaly constitutes nearly one-third of all craniofacial malformations. The overall worldwide incidence of craniofacial anomalies were 1 in 700 (1). Incidence of these anomalies in our population were 2 per 1000 live births (2). Surgeries on cleft lip and palate were very painful in the postoperative period. Intense pain in the postoperative period increases the requirement of opioids and other analgesic drugs (3). Orofacial blocks like nasopalatine, greater palatine, lesser palatine nerve blocks were successfully used in cleft palate surgeries either alone or in combination (4). Regional anaesthesia reduces the requirement of intraoperative analgesic and anaesthetic doses when it was given along with general anaesthesia (5). Regional anaesthesia in combination with general anaesthesia also prolongs the duration of analgesia, reduces opioid consumption and promotes early feeding in post operative period (6). Few studies have shown that the further addition of adjuvants like dexmedetomidine to local anaesthetic agents prolongs the analgesic duration without any significant systemic side effects $(7,8)$. Suprazygomatic approach to maxillary nerve block was simple and effective in cleft palate repair (9). In our study, we analysed the analgesic efficacy of dexmedetomidine with bupivacaine and bupivacaine alone in ultrasound guided suprazygomatic maxillary nerve (SMN) block in cleft palate repair. Although few studies were available on suprazygomatic nerve block, comparative studies with dexmedetomidine as adjuvant to local anaesthetics in maxillary nerve block were limited in our population. Primary outcomes assessed in this study were analgesia duration in postoperative period and postoperative pain scores using the children and infants postoperative pain scale (CHIPPS) (10). Secondary outcomes assessed were postoperative fentanyl consumption for 2 hours in Post Anaesthesia Care Unit (PACU) and postoperative paracetamol consumption in 24 hours.

\section{MATERIAL and METHODS}

We conducted this study in the Anaesthesiology department of a tertiary care teaching hospital from August 2020 to
February 2021. This study was approved by ethics committee of our institute and clinical trial registry of India. The design of the study was a randomized prospective double blind clinical trial. In this study the analgesic efficacy of $0.25 \%$ bupivacaine with saline was compared with $0.25 \%$ bupivacaine plus $1 \mu \mathrm{g}$ $\mathrm{kg}^{-1}$ of dexmedetomidine in bilateral SMN block for paediatric cleft palate repair. Children posted for cleft palate repair aged between 8 months to 5 years with ASA category I and II were enrolled in the study. Written and informed consents from parent/guardian were obtained on the day before surgery. Children who had coagulopathy, skin infection at block site, allergy for local anaesthetics and parent's refusal for consent were excluded. Preanaesthetic evaluation was done one day before surgery. All children were adequately fasted as per standard ASA fasting guidelines. Forty-six children were divided as group $A$ and group $B$ by computer generated block randomization (Figure 1). Twenty three children in Group A received $0.15 \mathrm{~mL} \mathrm{~kg}^{-1}$ of $0.25 \%$ bupivacaine with saline to make a volume of $2 \mathrm{~mL}$ on each side. In Group B, 23 children received a $2 \mathrm{~mL}$ of a solution containing $0.15 \mathrm{~mL} \mathrm{~kg}^{-1}$ of $0.25 \%$ bupivacaine with $0.5 \mu \mathrm{g} \mathrm{kg}^{-1}$ of dexmedetomidine on each side. All the solutions for SMN block were prepared in $5 \mathrm{~mL}$ syringes by anaesthesiologist not involved in the study and presented to another anaesthesiologist administering the block ensuring adequate blinding. Parents, anaesthesiologists, surgeons, and nurses collecting data were blinded to the drugs used in SMN block.

Premedication was given with oral midazolam $0.5 \mathrm{mg} \mathrm{kg}^{-1}$ 20 minutes prior to anaesthesia in the preoperative holding area (11). After shifting to operation theatre all children were monitored with electrocardiogram, oxygen saturation, noninvasive blood pressure before induction. After induction temperature and end tidal carbon dioxide were monitored. All children were induced with inhalational induction with $8 \%$ sevoflurane in $6 \mathrm{~L}$ of oxygen. After obtaining intravenous access sevoflurane concentration was decreased to $2 \%$, fentanyl $2 \mu \mathrm{g} \mathrm{kg}^{-1}$ and atracurium $0.5 \mathrm{mg} \mathrm{kg}^{-1}$ were given intravenously 3 minutes prior to intubation. Oral RAE (Ring, Adair and Elwyn) tube of appropriate size was used and it was fixed at the centre. Intraoperative maintenance of anaesthesia was done with sevoflurane, $33 \%$ oxygen and $67 \%$ nitrous oxide for obtaining a minimum alveolar concentration (MAC) of 1.2. Mechanical ventilation was done with volume 


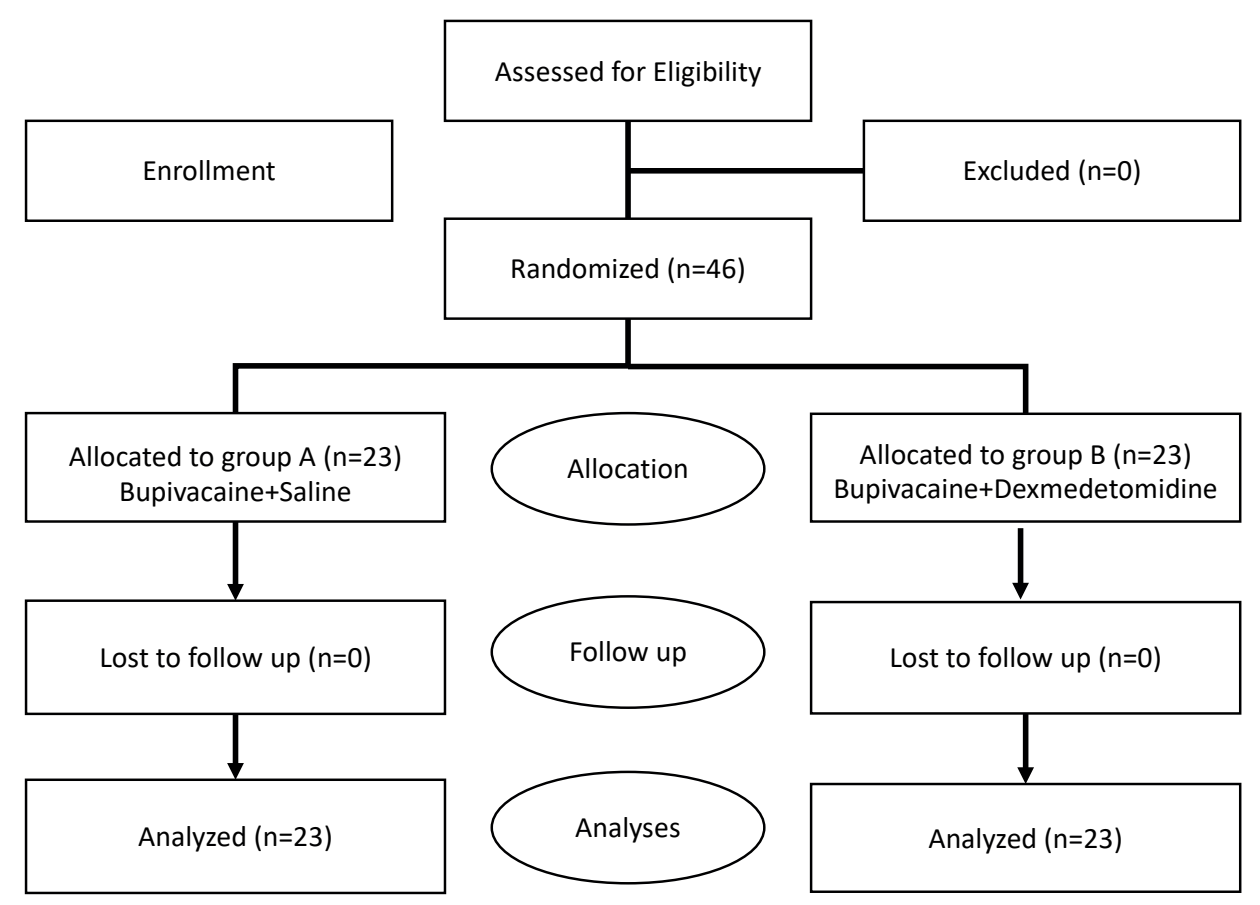

Figure 1: CONSORT diagram.

control ventilation. End tidal carbon dioxide levels were maintained between $35-40 \mathrm{~mm} \mathrm{Hg}$ throughout the procedure. Ultrasound guided bilateral suprazygomatic nerve block was given before starting the procedure. All the nerve blocks were performed by 4 senior anaesthesiologists with an experience of more than 10 years in ultrasound guided blocks. After induction subjects were placed in supine position and the head was kept neutrally before giving the block. After strict aseptic precautions, 8-13 MHz linear probe (SonoSite, Inc., Bothell, WA 98021 USA) was kept in infrazygomatic area over maxilla. The probe was adjusted horizontally to locate the pterygopalatine fossa situated in between the greater wing of sphenoid bone and maxilla (Figure 2A). The internal maxillary artery pulsation was identified within the pterygopalatine fossa. Using an out of plane approach a 23-gauge needle was inserted from suprazygomatic area (Figure 2B). Once the needle reaches the pterygopalatine fossa needle tip was identified and checked for absence of blood in aspiration test. After that $0.15 \mathrm{~mL} \mathrm{~kg}^{-1}$ of a diluted composition containing $0.25 \%$ bupivacaine with saline or $0.25 \%$ bupivacaine with $0.5 \mu \mathrm{g} \mathrm{kg}^{-1}$ dexmedetomidine was slowly injected. Local anaesthetic spreading was visualized with ultrasonography. The same technique is repeated on the other side. Immediate complications after block like local anaesthesia related systemic toxicity (disturbances in conduction, broad QRS complexes and changes in heart rhythm), the puncture site bleeding, changes in pupillary size and ocular lesions were noted. Surgery was started 15 minutes after nerve block. The block was considered to be failed if the children had a $20 \%$ raise in mean artery pressure and heart rate above baseline with surgical incision and these children were excluded from the study. Intravenous fentanyl was used for analgesia in failed block patients. Injection neostigmine $0.05 \mathrm{mg} \mathrm{kg}^{-1}$ and glycopyrrolate $0.01 \mathrm{mg} \mathrm{kg}^{-1}$ were given after the completion of surgical procedure. All children were extubated before shifting to PACU. Before shifting the patients to PACU vitals like heart rate, mean artery pressure, oxygen saturation were recorded. On arrival to PACU, the pain was assessed using CHIPPS by anaesthesiologist not involved in the study (12). Pain scores were assessed at 0 min and every 30 minutes till 2 hours in PACU. After 2 hours all children were shifted to ward. Pain scores in the ward were assessed by ward staff every 2 hours for 24 hours. CHIPPS score comprises of 5 parameters like facial expression, crying, posture of the trunk, the posture of the lower limb and motor restlessness. Each parameter has a score between 0 and 2, and the final score ranges from 0 to 10 . Children were considered to have pain if CHIPPS score more than 3 and these children were treated with fentanyl intravenously with a dose of $0.5 \mathrm{\mu g} \mathrm{kg}^{-1}$ for 2 hours in PACU. After shifting to the ward if the CHIPPS score was more than 3 intravenous paracetamol $15 \mathrm{mg} \mathrm{kg}^{-1}$ was given not exceeding 4 doses in 24 hours. All children were assessed for primary outcomes of analgesia duration and postoperative pain scores. Analgesia duration was defined as 

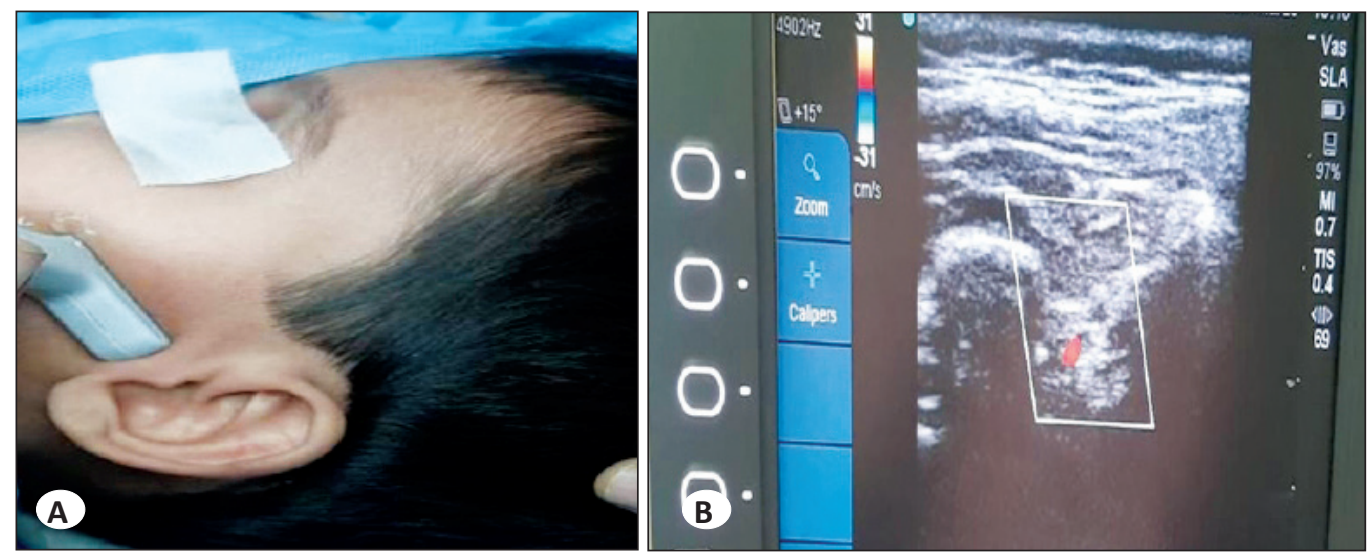

Figure 2: A) Probe position for SMN block.

B) Ultrasonographic view of SMN block with maxillary artery colour doppler.

the time from onset of the block to CHIPPS score of more than 3. Secondary outcomes assessed were postoperative fentanyl consumption in PACU for 2 hours, postoperative paracetamol consumption for 24 hours.

The study sample size was calculated based on a previous study. In the previous study mean analgesic duration of bupivacaine group was 14.2 hours with a standard deviation of 7 and the mean analgesic duration in bupivacaine with dexmedetomidine group was 22 hours with a standard deviation of 11 (13). The sample size was calculated for a power of $80 \%$ and $5 \%$ alpha error. Sample size came as 22 in each group and to account for the non-participation rate of about $5 \%$ another 1 subject was added and the final sample size was 23 in each group.

\section{Statistical Analysis}

Statistical analysis was performed by statistical package for social sciences (SPSS) 22 version of International Business Machines Corporation (IBM), Armonk, New York, USA. Demographic variables like age, gender, weight, ASA status were compared between the groups. Pain scores in postoperative period, analgesia duration and rescue analgesic consumption in postoperative period were compared among the groups. Vital datas like heart rate, systolic and diastolic blood pressures were measured. Normality for quantitative variables were checked with Shapiro-Wilks test. ShapiroWilks test $\mathrm{p}>0.05$ was considered as normal distribution. Mean and standard deviation were used for the analysis of normally distributed quantitative variables. The median and interquartile ranges were used for the analysis of nonnormally distributed quantitative variables. Frequency and proportion were used for categorical variables. Chi square test was used for assessment of statistical significance between the categorical variables. Independent sample t-test/MannWhitney $U$ tests were used to assess statistical significance between quantitative variables. $\mathrm{p}<0.05$ was considered as statistically significant.

\section{RESULTS}

Both the groups in terms of variables like age, gender, weight, ASA status and surgical duration were comparable (Table I). The mean analgesia duration in group $B$ was $12 \pm 4.73$ hours which was significantly longer when compared to group $A$ $5.41 \pm 3.9$ hours with a $p<0.003$ (Table II). Patients in group $B$ didn't require rescue opioid doses in PACU (Figure 3). Five patients in group $A$ required a single dose of rescue analgesia. In group $A$ one patient required 2 doses of rescue analgesia in PACU (Table III). In group B, 17 patients didn't require rescue paracetamol doses in ward when compared to eight patients of group A. Five patients of group $B$ and ten patients of group $A$ required single dose rescue paracetamol. One patient of group $B$ and three patients of group A required 2 doses of rescue paracetamol in ward. Two patients of group A required 3 doses of rescue paracetamol (Table IV). In group B majority of patients (74\%) didn't require rescue analgesia. The frequency of paracetamol consumption as a rescue analgesia was also less in group $B$ when compared to that of group A (Table IV). Postoperative CHIPPS pain scores at 0 min, 1 hr 30 min, 2 hrs, 4hrs, 6hrs and 8 hrs were significantly lower in group B compared to that of group A (Table V). Heart rate, systolic and diastolic blood pressures were comparable between the both groups except low systolic blood pressure in bupivacaine with dexmedetomidine group at 30 minutes after block.

\section{DISCUSSION}

In our study demographic profiles like age, weight, gender, ASA status and surgery duration were comparable. In group $B$ the mean analgesic duration was significantly longer when compared to that of group A. Similar to our study Obayah et al. also found that bupivacaine, dexmedetomidine combination in greater palatine nerve block prolongs the duration of analgesia up to 22 hours in cleft palate repair (13). Mostafa et al. found that bupivacaine, dexmedetomidine combination 
Table I: Demographic Characteristics

\begin{tabular}{lccc} 
Parameter & Group A (n=23) & Group B (n=23) & p \\
Age in months (Mean \pm SD) & $20.21 \pm 13.85$ & $17.54 \pm 13.13$ & 0.50 \\
\hline Weight in kgs (Mean \pm SD) & $9.33 \pm 1.96$ & $8.91 \pm 2.06$ & 0.49 \\
\hline Gender (male: female) (n) & $12: 11$ & $13: 10$ & 0.76 \\
Percentages (male: female) (\%) & $(52.17: 47.83)$ & $(56.52: 43.48)$ & 1.00 \\
\hline ASA status I:II (n) & $22: 1$ & $22: 1$ & 0.50 \\
\hline Duration of surgery (minutes) & $56.87 \pm 20.33$ & $53.13 \pm 17.67$ & \\
\hline
\end{tabular}

Group A (Bupivacaine with saline) Group B (Bupivacaine with dexmedetomidine); SD is standard deviation; Group A and Group B were compared with independent sample t test and chi square test.

Table II: Comparison of Mean Duration of Analgesia Between the Groups

\section{Group A ( $\mathbf{n}=23)$}

$5.41 \pm 3.9$

\section{Group B ( $\mathbf{n}=23)$}

$12 \pm 4.73$

Duration of analgesia in hours (Mean \pm SD)

Group A (Bupivacaine with saline) Group B (Bupivacaine with dexmedetomidine); SD is standard deviation; Both groups were compared with independent sample $t$ test.

Table III: Comparison of Rescue Analgesic Fentanyl Consumption Between the Groups in PACU

\begin{tabular}{|c|c|c|c|}
\hline Fentanyl consumption & Group A ( $n=23)$ & Group B (n=23) & $\mathbf{p}$ \\
\hline 0 dose $\mathrm{n}(\%)$ & $17(74)$ & $23(100)$ & \multirow{3}{*}{$0.032^{*}$} \\
\hline 1 dose n (\%) & $5(21.7)$ & $0(0)$ & \\
\hline 2 doses $n(\%)$ & $1(4.3)$ & $0(0)$ & \\
\hline
\end{tabular}

Group A (Bupivacaine with saline) Group B (Bupivacaine with dexmedetomidine); Chi square test was used; *Indicates $p$ value less than 0.05.

Table IV: Comparison of Rescue Analgesic Paracetamol Consumption Between the Groups in Postoperative Ward

\begin{tabular}{|c|c|c|c|}
\hline Paracetamol consumption & Group A (n=23) & Group B (n=23) & $\mathbf{p}$ \\
\hline 0 dose $n(\%)$ & $8(34.8)$ & $17(74)$ & \multirow{4}{*}{$0.048 *$} \\
\hline 1 dose $n(\%)$ & $10(43.5)$ & $5(21.7)$ & \\
\hline 2 doses $n(\%)$ & $3(13)$ & $1(4.3)$ & \\
\hline 3 doses $\mathrm{n}(\%)$ & $2(8.7)$ & $0(0)$ & \\
\hline
\end{tabular}

Group A (Bupivacaine with saline) Group B (Bupivacaine with dexmedetomidine); Chi square test was used for statistical analysis; *Indicates $p$ value less than 0.05 .

Table V: Comparison of CHIPPS Pain Score Between Groups

\begin{tabular}{lccc} 
Time & $\begin{array}{c}\text { Group A (n=23) } \\
\text { Median (IQR) }\end{array}$ & $\begin{array}{c}\text { Group B (n=23) } \\
\text { Median (IQR) }\end{array}$ & $\begin{array}{c}\text { Mann Whitney U test } \\
\text { (p) }\end{array}$ \\
\hline At 0 minutes in PACU & $1(0-2)$ & $0(0-1)$ & $0.04^{*}$ \\
\hline 30 min in PACU & $1(0-2)$ & $1(0-2)$ & 0.55 \\
\hline 1 hr in PACU & $1(0-3)$ & $1(0-2)$ & 0.24 \\
\hline 1 hr 30 min in PACU & $1(0-3)$ & $1(0-1)$ & $0.02^{*}$ \\
\hline 2 hrs in PACU & $2(1-3)$ & $1(0-1)$ & $<0.001^{*}$ \\
\hline At 4 hrs in ward & $2(2-3)$ & $1(0-1)$ & $<0.001^{*}$ \\
\hline At 6 hrs in ward & $2(1-3)$ & $1(0-2)$ & $0.006^{*}$ \\
\hline At 8 hrs in ward & $2(1-3)$ & $1(0-2)$ & $0.02^{*}$
\end{tabular}


Table V: Cont.

\begin{tabular}{lccc} 
Time & $\begin{array}{c}\text { Group A (n=23) } \\
\text { Median (IQR) }\end{array}$ & $\begin{array}{c}\text { Group B (n=23) } \\
\text { Median (IQR) }\end{array}$ & $\begin{array}{c}\text { Mann Whitney U test } \\
\text { (p) }\end{array}$ \\
\hline At 10 hrs in ward & $1(1-3)$ & $1(0-2)$ & 0.15 \\
\hline At 12 hrs in ward & $1(0-3)$ & $1(0-2)$ & 0.69 \\
\hline At 14 hrs in ward & $1(0-3)$ & $1(1-2)$ & 0.93 \\
\hline At 16 hrs in ward & $1(0-2)$ & $1(0-2)$ & 0.61 \\
\hline At 18 hrs in ward & $1(0-2)$ & $1(1-2)$ & 0.80 \\
\hline At 20 hrs in ward & $1(0-2)$ & $1(0-2)$ & 0.60 \\
\hline At 22 hrs in ward & $1(0-1)$ & $1(0-1)$ & 0.36 \\
\hline At 24 hrs in ward & $1(0-1)$ & $1(0-2)$ & 0.11 \\
\hline
\end{tabular}

Group A (Bupivacaine with saline) Group B (Bupivacaine with dexmedetomidine); IQR is interquartile range; Both groups were compared with Mann Whitney $U$ test; *Indicates $p$ value less than 0.05 .

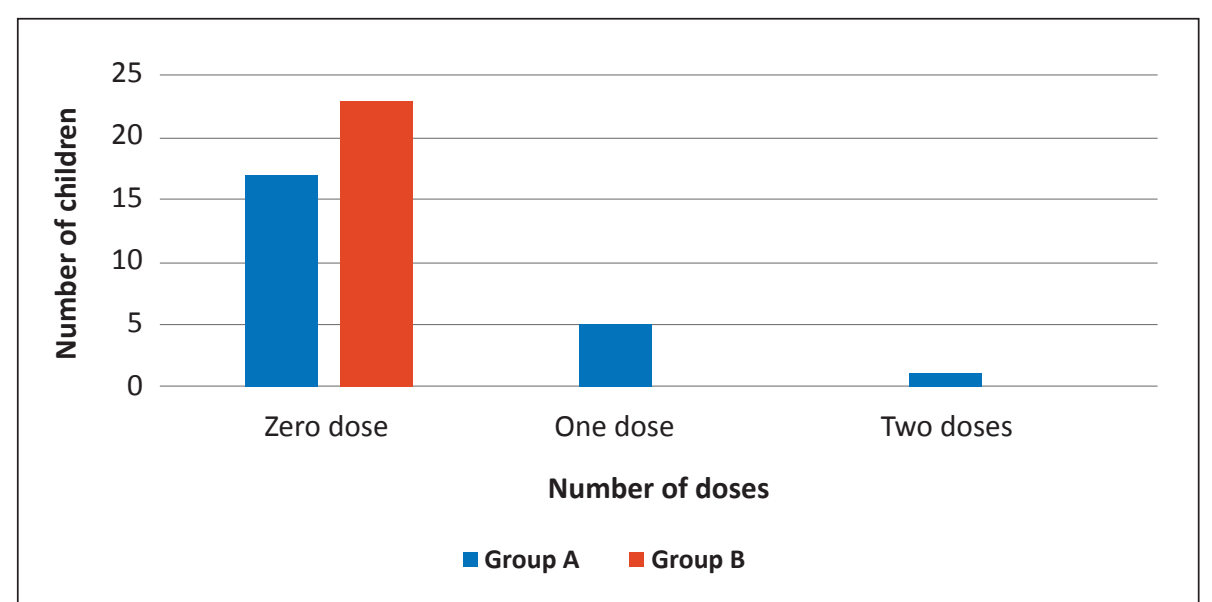

Figure 3: Comparison of fentanyl consumption between the groups. in SMN prolongs the duration of analgesia without any need for postoperative analgesia for 24 hours (14). Mostafa et al. also demonstrated that bilateral SMN block was effective, easy and safe method in cleft palate repair. In the same study, he found that postoperative analgesia duration was similar for both bupivacaine and levobupivacaine groups (15). In our study postoperative pain scores at $0 \mathrm{~min}, 1 \mathrm{hr} 30 \mathrm{~min}, 2 \mathrm{hrs}, 4$ hrs, $6 \mathrm{hrs}$ and $8 \mathrm{hrs}$ were significantly lower in group B when compared to that of group A. In contrast to our study Chiono et al. showed that no difference in pain scores in children receiving SMN block with ropivacaine and saline in the first few hours of surgery (10). Our results were similar to the study done by Elyazed and Mostafa by comparing bilateral SMN block, palatal block with general anaesthesia alone in cleft palate repair (16). Elyazed and Mostafa found that pain score was lower in children who received regional anaesthesia along with general anaesthesia compared to the one who received only general anaesthesia (16). Mostafa et al. found that the dexmedetomidine in combination with bupivacaine for bilateral SMN block reduces modified CHEOPS score significantly when compared to plain bupivacaine alone (14).
Obayah et al. also found that dexmedetomidine along with bupivacaine in greater palatine nerve block leads to greater reduction in the postoperative pain scores when compared to bupivacaine alone (13).

Chiono et al. reported that bilateral SMN block with ropivacaine reduced the postoperative morphine consumption by $50 \%$ and also reduces the need for continuous morphine infusion (1 vs 9 patients) (10). The morphine requirement was lower $\left(104.3 \mathrm{\mu g} \mathrm{kg}^{-1}\right)$ in ropivacaine group compared to that in the saline group $\left(205.2 \mathrm{\mu g} \mathrm{kg}^{-1}\right)$. In our study group B patients didn't require the rescue fentanyl doses in PACU while six patients of group A required rescue fentanyl dose in PACU (Figure 3). Seventeen patients in group $B$ didn't require rescue paracetamol dose in ward. Eight patients in group A didn't require rescue paracetamol dose in ward. The number of rescue analgesic doses used were also less in group B when compared to that of group A. Obayah et al. also reported that in greater palatine nerve block for cleft palate repair all subjects in the bupivacaine group required rescue analgesic medication (13). Rescue analgesic medication was given only for $66 \%$ of patients when dexmedetomidine was added as adjuvant to 
bupivacaine for greater palatine nerve block. A multicentre study by Echaniz et al. showed that bilateral SMN blocks required less intraoperative nalbuphine and fentanyl consumption than infraorbital and palatine nerve blocks (17). Elyazed et al. also shown that postoperative rescue analgesic pethidine consumption was lower in regional anaesthesia groups when compared to general anaesthesia alone group (16). Binet et al. in a retrospective study showed that intraoperative morphine requirement was less in the SMN block group than general anaesthesia alone and the time to extubation was shorter and postoperative nalbuphine requirement also significantly lower in the SMN block group (18). Similarly, Mesnil et al. showed that postoperative nalbuphine consumption was required in $18 \%$ of patients compared to $80 \%$ of patients in general anesthesia alone (19). In this study except for slight decrease in systolic blood pressure at 30 minutes, heart rate, diastolic and systolic blood pressure between the groups were comparable. We didn't find any hemodynamic complications like hypotension and bradycardia in group B. Similarly Obayah et al. also reported that hemodynamic parameters were comparable between the groups (13). Obayah et al. also didn't find any complications like hypotension and bradycardia in the dexmedetomidine group (13).

The main limitation of our study was we didn't assess sedation and agitation scores in the postoperative period.

\section{CONCLUSION}

Dexmedetomidine along with bupivacaine in SMN nerve block resulted in prolongation of analgesia duration, reduction in postoperative pain scores and reduction in rescue analgesic opioid and paracetamol doses in cleft palate surgeries.

\section{AUTHOR CONTRIBUTIONS}

Conception or design of the work: AMR, SKS, PS, VRKK, AM, $\mathrm{AP}, \mathrm{MV}$

Data collection: AMR, SKS, PS, VRKK, AM, AP, MV

Data analysis and interpretation: AMR, SKS, PS, VRKK, AP, MV

Drafting the article: AMR, SKS, PS, VRKK, AM, AP, MV

Critical revision of the article: AMR, SKS, PS, VRKK, AM, AP, MV

Other (study supervision, fundings, materials, etc): Department of Anaesthesiology, Sri Ramachandra Institute of Higher Education and Research (SRIHER), Porur, Chennai.

All authors (AMR, SKS, PS, VRKK, AM, AP, MV) reviewed the results and approved the final version of the manuscript.

\section{REFERENCES}

1. Murray JC. Gene/environment causes of cleft lip and/or palate. Clin Genet 2002;61:248-56.

2. Kharbanda OP, Agrawal K, Khazanchi R, et al. Clinical profile and treatment status of subjects with cleft lip and palate anomaly in India: Preliminary report of a three-center study. J Cleft Lip Palate Craniofacial Anomalies 2014;1:26-33.

3. Roulleau P, Gall O, Desjeux L, Dagher C, Murat I. Remifentanil infusion for cleft palate surgery in young infants. Paediatr Anaesth 2003;13:701-7.

4. Reena, Bandyopadhyay KH, Paul A. Postoperative analgesia for cleft lip and palate repair in children. J Anaesthesiol Clin Pharmacol 2016;32(1):5-11.

5. Kettner SC, Willschke H, Marhofer P. Does regional anaesthesia really improve outcome? Br J Anaesth 2011;107 Suppl 1:i90-95.

6. Jakobsson J, Johnson MZ. Perioperative regional anaesthesia and postoperative longer-term outcomes. F1000Res 2016;5:F1000.

7. Kirksey MA, Haskins SC, Cheng J, Liu SS. Local anesthetic peripheral nerve block adjuvants for prolongation of analgesia: A systematic qualitative review. PLoS One 2015;10(9):e0137312.

8. Agarwal S, Aggarwal R, Gupta P. Dexmedetomidine prolongs the effect of bupivacaine in supraclavicular brachial plexus block. J Anaesthesiol Clin Pharmacol 2014;30(1):36-40.

9. Sola C, Raux O, Savath L, Macq C, Capdevila X, Dadure C. Ultrasound guidance characteristics and efficiency of suprazygomatic maxillary nerve blocks in infants: A descriptive prospective study. Paediatr Anaesth 2012;22(9):841-6.

10. Chiono J, Raux O, Bringuier S, et al. Bilateral suprazygomatic maxillary nerve block for cleft palate repair in children: a prospective, randomized, double-blind study versus placebo. Anesthesiology 2014;120(6):1362-9.

11. Davies FC, Waters M. Oral midazolam for conscious sedation of children during minor procedures. J Accid Emerg Med 1998;15:244-8.

12. Büttner $W$, Finke $W$, Hilleke $M$, Reckert $S$, Vsianska $L$, Brambrink A. Development of an observational scale for assessment of postoperative pain in infants. Anasthesiol Intensivmed Notfallmed Schmerzther 1998;33:353-61.

13. Obayah GM, Refaie A, Aboushanab O, Ibraheem N, Abdelazees $M$. Addition of dexmedetomidine to bupivacaine for greater palatine nerve block prolongs postoperative analgesia after cleft palate repair. Eur J Anaesthesiol 2010;27:280-4.

14. Mostafa MF, Aal FAA, Ali IH, Ibrahim AK, Herdan R. Dexmedetomidine during suprazygomatic maxillary nerve block for pediatric cleft palate repair, randomized doubleblind controlled study. Korean J Pain 2020;33(1):81-9. 
15. Mostafa MF, Herdan R, Elshazly M. Comparative study of levobupivacaine and bupivacaine for bilateral maxillary nerve block during pediatric primary cleft palate surgery: A randomized double-blind controlled study. Korean J Anesthesiol 2018;71:135-40.

16. Elyazed MMA, Mostafa SF. Bilateral suprazygomatic maxillary nerve block versus palatal block for cleft palate repair in children: A randomized controlled trial. Egypt J Anaesth 2018;34:83-8.
17. Echaniz G, De Miguel M, Merritt G, et al. Bilateral suprazygomatic maxillary nerve blocks vs. infraorbital and palatine nerve blocks in cleft lip and palate repair: A doubleblind, randomised study. Eur J Anaesthesiol 2019;36:40-7.

18. Binet A, Thinnes J, Amory C, et al. Role of bilateral suprazygomatic maxillary nerve block in primary surgery for soft palate cleft and soft-hard palate cleft. PACCJ 2015;3:1117.

19. Mesnil M, Dadure C, Captier G, et al. A new approach for peri-operative analgesia of cleft palate repair in infants: the bilateral suprazygomatic maxillary nerve block. Paediatr Anaesth 2010;20:343-9. 